\title{
OPTIMALISASI KPU DALAM PENINGKATAN PARTISIPASI MASYARAKAT DALAM PEMILU
}

\section{DUDI WARSUDIN}

Dosen Fakultas Hukum Universitas Pasundan Bandung, Jalan Lengkong Besar No. 68 Bandung, Telp. (022) 4262226, Fax. (022) 4217340 Email: dudiwarsudin@gmail.com.

\begin{abstract}
ABSTRAK
Merupakan suatu keniscayaan bahwa dalam negara modern, pemilu merupakan entry point bagi terbangunnya suatu pemerintahan yang demokratis. Dalam kerangka ini, prinsip kedaulatan rakyat menjadi roh bagi setiap gerak langkah penyelenggaraan pemilu. Terselenggaranya pemilu yang langsung, umum, bebas, rahasia, jujur dan adil, bukanlah pekerjaan yang mudah. Sebagai amanat konstitusi, yang pada hakikatnya merupakan kebijakan publik di bidang politik dan pemerintahan, sangat jelas bahwa implementasinya akan dipengaruhi oleh berbagai faktor. Salah satu faktor itu adalah institusi penyelenggara, sehingga dengan demikian hal inilah yang harus jadi kajian cermat dari setiap aparatur institusi penyelenggara pemilu pada berbagai level. $\mathrm{Di}$ antara beberapa jenis pemilu yang telah diselanggarakan, tampak bahwa pemilu Bupati dan Wakil Bupati yang paling menarik untuk dicermati. Hal ini antara lain karena setting sosiopolitik dan sosiokultural yang melingkupinya yang multikompleks sehingga potensi konflik dalam penyelenggaraaannya akan jauh lebih besar dibandingkan dengan jenis pemilu lainnya. Tingkat partisipasi masyarakat dalam pemilu, khususnya pada kegiatan pemungutan dan perhitungan suara menjadi perhatian banyak kalangan. Di beberapa daerah provinsi, kota dan kabupaten yang telah melaksanakan pemilu, tampak bahwa tingkat partisipasi ini mengalami penurunan dari satu pemilu ke pemilu lainnya. Dengan itu penulis tertarik terhadap bagaimana Optimalisasi Peran Kelembagaan KPU dalam peningkatan partisipasi masyarakat dalam Pemilu.
\end{abstract}

Kata kunci : Optimalisasi, Peningkatan Partisipasi Masyarakat, Pemilu. 


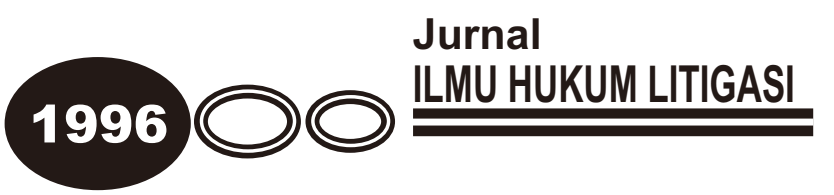

\begin{abstract}
It was undoubtedly that in the modern state, Election is the entry point for the establishment of a democratic government. Within this framework, the principle of sovereignty has become the spirit for election in every move. The implementation of direct elections, public, free, confidential, honest and fair, is not an easy job. As it is mandated by the constitution, which is in essence a public policy in the fields of politics and governance, it is clear that the implementation will be influenced by various factors. One of the factor is organizing institution, thus it is must be carefully study by each of election management official at various levels. Among the several types of elections that had been held, it appears that the election of Regent is the most interesting to observe. This is partly due to socio-political and socio-cultural setting that surrounded the multi-complex so that the potential for conflict in its even will be far greater than with other types of elections. Level of community participation in the elections, especially on polling and counting activities have become attention of many people. In some provinces, cities and districts that have conducted the election, it appears that the participation rate has decreased from one election to another. Because of the matter above, the writer is interested to write about how to Optimize the Role of Institutional Commission in order to increased participation of community in the election.
\end{abstract}

Keyword : Optimize, increased participation of community, the election. 


\section{(1)}

\section{PENDAHULUAN}

\section{Merupakan suatu keniscayaan bahwa dalam negara}

modern, pemilu merupakan entry point bagi terbangunnya suatu

pemerintahan yang demokratis. Dalam kerangka ini, prinsip kedaulatan rakyat menjadi roh bagi setiap gerak langkah penyelenggaraan pemilu. Dengan pemilu pula, suatu pemerintahan mendapatkan legitimasinya. Hal ini sejalan dengan apa yang dikemukakan Ball bahwa Elections are primarly a means of legitimizing the right of the rulers to govern (1975: 129).

Terselenggaranya pemilu yang langsung, umum, bebas, rahasia, jujur dan adil, bukanlah pekerjaan yang mudah. Sebagai amanat konstitusi, yang pada hakikatnya merupakan kebijakan publik di bidang politik dan pemerintahan, sangat jelas bahwa implementasinya akan dipengaruhi oleh berbagai faktor. Salah satu faktor itu adalah institusi penyelenggara, sehingga dengan demikian hal inilah yang harus jadi kajian cermat dari setiap aparatur institusi penyelenggara pemilu pada berbagai level. Sebagaimana dinyatakan oleh Edward III ... The implementation of every policy is a dynamic process, which involves the interaction of many variables (1980: 10). Pun demikian, kompleksitas implementasi penyelenggaraan pemilu, melibatkan interaksi 


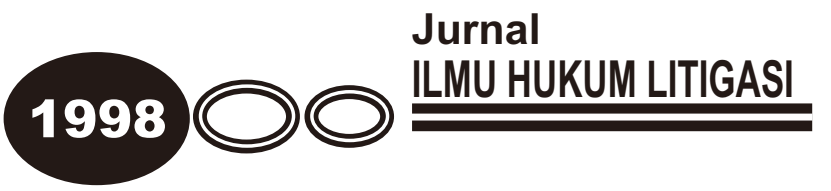

berbagai faktor diantaranya politikal, sosial, teknis, manajerial, psikologis bahkan teknologis.

Menjadi tugas yang amat berat tapi mulia bagi KPU dan jajarannya (KPU Provinsi, KPU Kabupaten/Kota, sampai ke jajaran pelaksana adhoc di tingkat paling bawah) untuk mengimplementasikannya. Sebagai lembaga yang bersifat nasional, tetap dan mandiri, kepadanya dihadapkan tantangan nyata untuk mengemban tugas, wewenang dan kewajibannya dalam mengusung visi demokratisasi dan kedaulatan rakyat. KPU Kabupaten/Kota sebagai bagian integral dari KPU, tentu saja harus tampil paling depan untuk kepentingan ini. KPU sebagai penyelenggara pemilu tentunya harus menjalankan tugas pokoknya, yang salah satu tahapannya adalah melaksanakan sosialisasi artinya mengkomunikasikan sesuatu kegiatan yang akan dilaksanakan kepada masyarakat terkait kegiatan KPU yang akan dilaksanakan.

Di antara beberapa jenis pemilu yang telah diselenggarakan, tampak bahwa pemilu Bupati dan Wakil Bupati yang paling menarik untuk dicermati. Hal ini antara lain karena setting sosiopolitik dan sosiokultural yang melingkupinya yang multikompleks sehingga potensi konflik dalam penyelenggaraannya akan jauh lebih besar dibandingkan dengan jenis pemilu lainnya. Pada sisi ini, tingkat partisipasi masyarakat dalam pemilu, khususnya 
pada kegiatan pemungutan dan perhitungan suara menjadi perhatian banyak kalangan. Di beberapa daerah provinsi, kota dan kabupaten yang telah melaksanakan pemilu, tampak bahwa tingkat partisipasi ini mengalami penurunan sebagai contoh dalam pemilihan Bupati dan Wakil Bupati Kabupaten Bandung tahun 2010, yang mengalami dua putaran dimana putaran pertama dari DPT 2.129.802 orang, dan partisipasi masyarakat yang mencoblos mencapai $64,99 \%$, sedangkan dalam putaran kedua DPT 2.129.802 orang, dan partisipasi masyarakat hanya mencapai $61,56 \%$ (sumber data KPU Kabupaten Bandung).

Berdasarkan latar belakang pemikiran tersebut dapat diungkapkan sekurang-kurangnya permasalahan sebagai berikut:

a. Bagaimanakah optimalisasi peran kelembagaan KPU Kabupaten sebagai penyelenggara pemilu Kepala Daerah dan Wakil Kepala Daerah ?

b. Bagaimana peran aparatur (SDM) untuk mendorong partisipasi masyarakat Dalam Pemilu ? 


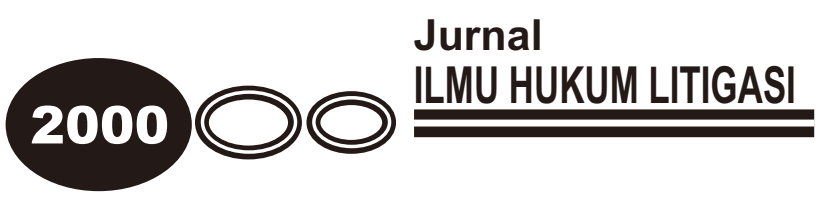

\section{PEMBAHASAN}

A. Optimalisi Peran Kelembagaan Penyelenggara Pemilu

Dalam berbagai literatur telah dikupas tuntas bagaimanakah eksistensi dan peran institusi yang tugas dan otoritasnya melaksanakan berbagai keputusan/kebijakan organisasi. Meminjam istilah Henry Mintzberg, dalam konteks posisinya sebagai bagian integral dari KPU secara nasional maka KPU Kabupaten Bandung dapat dipandang sebagai the operating core (dalam Robbins: 1990, 278). Dengan kata lain, KPU Kabupaten Bandung berperan untuk mengimplementasikan seluruh keputusan/kebijakan organisasi tentang berbagai aspek kepemiluan yang telah ditetapkan oleh KPU dalam bentuk berbagai Peraturan KPU.

Dengan terminologi yang sedikit berbeda tapi esensinya sama, beberapa pakar kebijakan publik telah mengintrodusir peran penting organisasi/birokrasi pelaksana berbagai keputusan/kebijakan organisasional ini, termasuk kebijakan/keputusan yang menyentuh banyak kepentingan publik seperti pemilu. Diantaranya adalah bureaucratic structure (Edwards III, 1989: 11), organization/bureaucracy (Jones, 1984: 170) dan program implementers (Grindle, 1980: 11). 
Peran kelembagaan KPU Kabupaten/Kota sebagai penyelenggara pemilu kepala daerah dan wakil kepala daerah, secara normatif yuridis tertuang dalam Pasal 10 ayat (3) dan ayat (4) Undang-Undang No. 22 Tahun 2007 tentang Penyelenggara Pemilu. Secara rinci tugas dan wewenang KPU Kabupaten dalam pemilu Bupati dan Wakil Bupati adalah:

a. Merencanakan program, anggaran, dan jadwal Pemilu Kepala Daerah dan Wakil Kepala Daerah Kabupaten;

b. Menyusun dan menetapkan tata kerja KPU Kabupaten, PPK, PPS, dan KPPS dalam Pemilu Kepala Daerah dan Wakil Kepala Daerah Kabupaten dengan memperhatikan pedoman dari KPU dan/atau KPU Provinsi;

c. Menyusun dan menetapkan pedoman yang bersifat teknis untuk tiap-tiap tahapan penyelenggaraan pemilu Kepala Daerah dan Wakil Kepala Daerah Kabupaten berdasarkan perundang-undangan;

d. Membentuk PPK, PPS, dan KPPS dalam Pemilu Kepala Daerah dan Wakil Kepala Daerah Kabupaten dalam wilayah kerjanya;

e. Mengkoordinasikan, menyelenggarakan, dan mengendalikan semua tahapan penyelenggaraan Pemilu Kepala Daerah dan Wakil Kepala Daerah Kabupaten berdasarkan peraturan perundang-undangan dengan memperhatikan pedoman dari KPU dan/atau KPU Provinsi; 


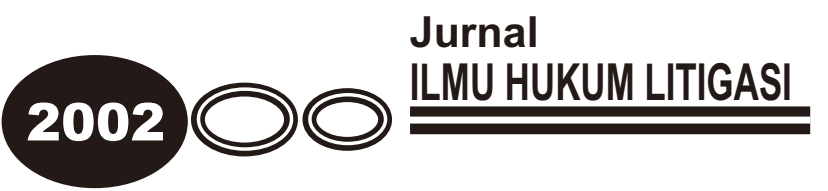

f. Memutahirkan data pemilih berdasarkan data kependudukan dan menetapkan data pemilih sebagai daftar pemilih;

g. Menetapkan pasangan calon kepala daerah dan wakil kepala daerah kabupaten yang telah memenuhi persyaratan;

h. Menetapkan dan mengumumkan hasil rekapitulasi perhitungan suara Pemilu Kepala Daerah dan Wakil Kepala Daerah Kabupaten berdasarkan rekapitulasi hasil perhitungan suara dari seluruh PPK di wilayah kabupaten dengan membuat berita acara penghitungan suara dan sertifikat hasil penghitungan suara;

i. Membuat berita acara penghitungan suara serta membuat sertifikat penghitungan suara dan wajib menyerahkannya kepada saksi peserta Pemilu, Panwaslu Kabupaten, dan KPU Provinsi;

j. Menerbitkan keputusan KPU Kabupaten untuk mengesahkan hasil Pemilu Kepala Daerah dan Wakil Kepala Daerah Kabupaten dan mengumumkannya;

k. Mengumumkan pasangan calon kepala daerah dan wakil kepala daerah kabupaten terpilih dan membuat berita acaranya;

I. Melaporkan hasil Pemilu Kepala Daerah dan Wakil Kepala Daerah Kabupaten kepada KPU melalui KPU Provinsi; 
m. Memeriksa pengaduan dan/atau laporan adanya pelanggaran kode etik yang dilakukan oleh PPK, PPS, dan KPPS;

n. Menindaklanjuti dengan segera temuan dan laporan yang disampaikan oleh Panwaslu Kabupaten;

o. Menonaktifkan sementara dan/atau mengenakan sanksi administratif kepada anggota PPK, PPS, sekretaris KPU Kabupaten, dan pegawai sekretariat KPU Kabupaten/Kota yang terbukti melakukan tindakan yang mengakibatkan terganggunya tahapan penyelenggaraan pemilu yang sedang berlangsung berdasarkan rekomendasi Panwaslu Kabupaten dan ketentuan peraturan perundang-undangan;

p. Melaksanakan sosialisasi penyelenggaraan Pemilu Kepala Daerah dan Wakil Kepala Daerah dan/atau yang berkaitan dengan tugas KPU Kabupaten kepada masyarakat;

q. Melakukan evaluasi dan membuat laporan penyelenggaraan Pemilu Kepala Daerah dan Wakil Kepala Daerah Kabupaten;

r. Menyampaikan hasil Pemilu Kepala Daerah dan Wakil Kepala Daerah Kabupaten kepada Dewan Perwakilan Rakyat Daerah Provinsi, Menteri Dalam Negeri, Bupati, dan Dewan Perwakilan Rakyat Daerah Kabupaten; 


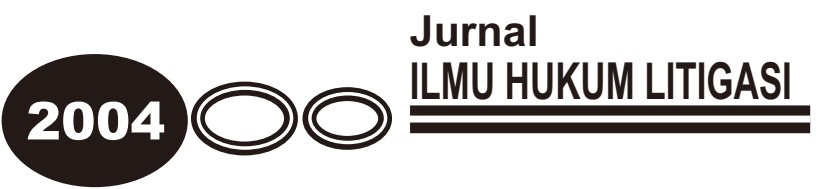

dan melaksanakan tugas dan wewengang lain yang diberikan oleh KPU, KPU Provinsi dan/atau undang-undang.

Adapun kewajibannya adalah:

a. Melaksanakan semua tahapan penyelenggaraan pemilu dengan tepat waktu;

b. Memperlakukan peserta pemilu dan pasangan calon secara adil dan setara;

c. Menyampaikan semua informasi penyelenggaraan pemilu kepada masyarakat;

d. Melaporkan pertanggungjawaban penggunaan anggaran sesuai dengan peraturan perundang-undangan;

e. Menyampaikan laporan pertanggungjawaban semua kegiatan penyelenggaraan pemilu kepada KPU melalui KPU Provinsi;

f. Memelihara arsip dan dokumen pemilu serta mengelola barang inventaris KPU Kabupaten berdasarkan peraturan perundang-undangan;

g. Menyampaikan laporan periodik mengenai tahapan penyelenggaraan pemilu kepada KPU dan KPU Provinsi serta menyampaikan tembusannya kepada Bawaslu; 
h. Membuat berita acara pada setiap rapat pleno KPU Kabupaten dan ditandatangani oleh ketua dan anggota KPU Kabupaten;

i. Melaksanakan kewajiban lain yang diberikan oleh KPU dan KPU Provinsi; dan

j. Melaksanakan kewajiban lain yang diberikan oleh peraturan perundang undangan.

Semua tahapan tersebut di atas itu dijabarkan dalam keputusan KPU Kabupaten/Kota, bukan dalam peraturan KPU yang sifatnya mengatur, karena berdasarkan Undang-Undang Nomor 15 tahun 2011 tentang penyelenggara pemilu, KPU Propinsi, Kabupaten/Kota tidak diberi kewenangan untuk membuat aturan yang sifatnya mengatur (PKPU), namun hanya diberi kewenangan membuat keputusan sebagai pedoman teknis dari PKPU.

Merujuk kepada ketentuan normatif tentang tugas dan wewenang KPU Kabupaten/Kota dalam penyelenggaraan pemilu, tugas dan wewenang kelembagaannya adalah sebagai berikut: 


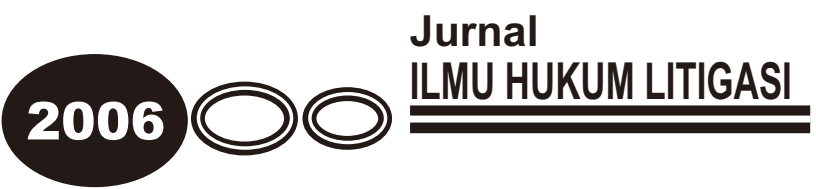

a. Merencanakan program, anggaran, dan jadwal pemilu di kabupaten.

Perencanaan pada hakikatnya adalah serangkaian kegiatan berfikir yang antisipatif tetapi realistik. Perencanaan pemilu akan bersangkut paut dengan dimensi ruang, waktu, fasilitas, sumber daya dan ruang lingkup. Suatu rencana sebagai produk suatu perencanaan harus mengakomodasi kemungkinan adanya modifikasi. Dalam kaitan ini, keajegan dan fleksibilitas sangat penting ditunjukkan oleh segenap aparatur penyelenggara pemilu.

b. Menyusun dan menetapkan tata kerja KPU Kabupaten, PPK, PPS, dan KPPS.

Dalam kegiatan ini, meskipun sepenuhnya telah ada pedoman yang ditetapkan oleh KPU dalam kenyataannya dituntut kejelian dan terobosan disesuaikan dengan karakteristik masing-masing daerah.

c. Menyusun dan menetapkan pedoman teknis untuk tiap tahapan penyelenggaraan pemilu.

Keberadaan pedoman ini sangat penting dan menentukan, karena dalam beberapa Peraturan KPU acapkali ditemukan di dalamnya ketidakjelasan, sehingga oleh karenanya perlu ada derivasi yang lebih operasional, teknis 
dan aplikatif. Keluasan pandangan, wawasan dan keberanian mengambil keputusan menjadi bagian penting dari tahap ini.

d. Pembentukan PPK, PPS, dan KPPS.

Sebagai tangan kanan, kepanjangantangan dan ujung tombak penyelenggaraan pemilu, pembentukannya harus tepat dan cermat sesuai dengan jadwal dan kebutuhan. Pertimbangan-pertimbangan personal, primordial dan nepotistik harus dibuang jauh-jauh dalam rekrutmennya demi terlahirnya penyelenggara yang kapabel.

e. Mengoordinasikan, menyelenggarakan dan mengendalikan semua tahapan pemilu.

Tahapan pelaksanaan harus mencermati berbagai faktor yang mempengaruhi. Budaya politik yang masih bercorak subyek dan bahkan parochial selain kemungkinan munculnya neofeodalisme akan menjadi hal yang patut diperhatikan. Prinsip kebersamaan dalam rangka pencapaian tujuan organisasi harus dipegang teguh. Selain itu mesti dibangun pola hubungan kerja yang sifat saling menghargai tapi impersonalistik.

f. Memutakhirkan Data Pemilih.

Meskipun realitanya KPU Kabupaten adalah pengguna akhir data kependudukan yang diterima dari Pemerintah Daerah, cq. Dinas 


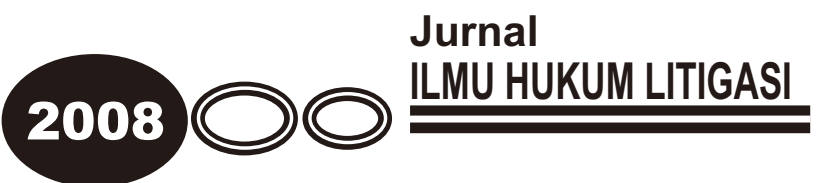

Kependudukan dan Catatan Sipil, tetapi kualitas dari tahap ini akan sangat tergantung kepada kecermatan KPU dan seluruh jajarannya dalam meng-update dan mengolah data kependudukan menjadi daftar pemilih. Koordinasi dan supervisi KPU Kabupaten terhadap PPK, PPS dan khususnya PPDP sangat penting dan menentukan. Ketersediaan sumbersumber daya organisasi, khususnya dana dan informasi sangat penting bagi akurasi daftar pemilih ini.

g. Menetapkan pasangan calon Kepala daerah dan Wakil Kepala Daerah. Tahap ini diawali oleh proses pendaftaran bakal pasangan calon, baik yang berasal dan diusulkan partai politik maupun perseorangan. Kehatihatian dan sikap teguh pada aturan akan sangat membantu tugas-tugas dan wewenang kelembagaan. Seringkali konflik internal partai politik terbawa-bawa dalam tahap ini dan masuk ke pusaran internal penyelenggara. Hal lain yang acapkali menjadi perhatian publik adalah akurasi pada tahap verifikasi persyaratan bakal calon, baik syarat individu, syarat kelembagaan parpol maupun syarat dukungan dalam bentuk fotokopi KTP warga masyarakat. 
h. Menetapkan dan mengumumkan hasil rekapitulasi penghitungan suara pemilu.

Meskipun tahap ini sangat ditunggu-tunggu tetapi perlu kehati-hatian dan kecermatan. Prinsip keadilan dan non-partisan menjadi sangat relevan untuk dipegang teguh, karena godaan politik akan terasa sangat besar menghadang semua jajaran penyelenggara.

i. Membuat berita acara penghitungan suara dan sertifikat penghitungan suara.

Pada kegiatan ini aspek penting yang harus diperhatikan adalah ketelitian dalam entry dan pengolahan data. Kesalahan acapkali terjadi meskipun bukan sebagai sesuatu yang disengaja tetapi lebih bersifat human error.

j. Menerbitkan keputusan KPU Kabupaten untuk mengesahkan hasil pemilu dan mengumumkannya.

Meskipun terbitnya keputusan dalam bentuk naskah surat keputusan ini hanya merupakan aspek legalitas dari sebuah keputusan (beschikking), tetapi tetap saja diperlukan ketelitian dalam penyusunannya. Pemahaman aparat penyelenggara terhadap aspek-aspek legal drafting akan sangat membantu tahap ini. 


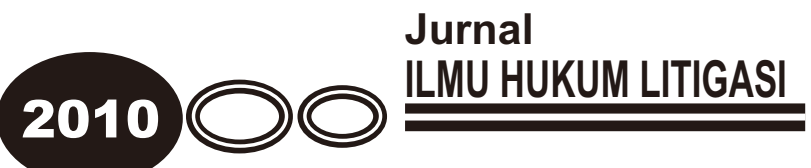

1. Mengumumkan pasangan calon Bupati dan Wakil Bupati terpilih dan membuat berita acaranya. Kegiatan ini lebih bersifat formalistik dalam bentuk publikasi kepada publik secara luas. Namun demikian, tetap diperlukan adanya kehati-hatian dalam penyusunannya.

2. Melaporkan hasil pemilu kepada KPU melalui KPU Provinsi. Acapkali kegiatan penyusunan laporan terabaikan di tengah hiruk pikuknya penyelenggaraan pemilu. Padahal pelaporan ini merupakan salah satu fungsi manajemen pemilu yang tidak kalah penting dibanding fungsi-fungsi lainnya.

3. Memeriksa pengaduan dan/atau laporan adanya pelanggaran kode etik yang dilakukan oleh PPK, PPS, dan KPPS. Harus disadari bahwa dalam tahap ini dampak psikologis kultural akan sangat dominan. Penegakan kode etik akan sangat kontributif bagi terlahirnya postur penyelenggara yang kredibel.

4. Menindaklanjuti dengan segera temuan dan laporan yang disampaikan oleh Panwaslu. Berbagai tahapan dalam penyelenggaraan pemilu tidak akan terbebas dari kemungkinan adanya konflik, insiden dan hal-hal kontra produktif bagi efektivitas penyelenggaraannya. Pada sisi lain meskipun KPU Kabupaten merupakan institusi 
independen dan mandiri dalam penyelenggaraan pemilu, pada hakikatnya merupakan bagian inheren dari sistem politik. Dalam konteks ini, sebagaimana dikemukakan Gabriel A. Almond, salah satu kapabilitas yang harus dikembangkan adalah responsivitas. Artinya sejauh mana institusi-institusi dalam suatu sistem politik cepat tanggap terhadap berbagai input yang berasal dari lingkungan. Dengan kata lain, KPU Kabupaten harus membuka telinga dan mata dengan lebar terhadap segala macam informasi yang datang dari luar dirinya.

5. Menonaktifkan sementara dan/atau mengenakan sanksi administratif. Hal penting yang harus diperhatikan adalah fact finding terhadap dugaan terjadinya tindakan yang mengganggu tahapan pemilu. Kelugasan dan impersonalitas dalam rangka ini harus dikedepankan.

6. Melaksanakan sosialisasi penyelenggaraan pemilu. Diperolehnya informasi-informasi kepemiluan oleh masyarakat memang bukan satusatunya monopoli kerja KPU. Tetapi publik akan selalu mengaitkan berbagai kisruh penyelenggaraan pemilu dengan rendahnya intensitas sosialisasi ini. 


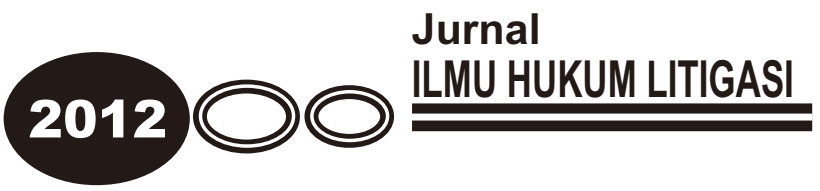

7. Melakukan evaluasi dan membuat laporan penyelenggaraan pemilu. Upaya menemukan hal-hal yang distortif dalam pelaksanaan tugas bukanlah perkara mudah. Dalam hal ini evaluasi secara seksama, obyektif, dan komprehensif sangat diperlukan. Hal ini menjadi bagian penting bagi tersusunnya suatu laporan yang akurat.

8. Menyampaikan hasil pemilu kepada DPRD Provinsi, Bupati dan DPRD Kabupaten. Penyampaian hasil pemilu secara tepat waktu sesuai jadwal akan sangat menentukan kinerja organisasi. Hal ini mengingat publik akan selalu menunggu apa yang menjadi finalisasi dari tugas kepemiluannya.

9. Melaksanakan tugas dan wewenang Iain. Dalam realitanya akan terdapat kaitan tugas yang bersumber dari ketentuan lain sejauh menyangkut kepemiluan. Dalam rangka ini, prinsip integrasi dan sinkronisasi menjadi bagian penting untuk efektivitas tugas. Orientasi pelaksanaan tugas berjalan secara simultan dan sinergis ke berbagai arah (vertical, horisontal, dan diagonal). 
Optimalisasi kewajiban lembaga penyelenggara pemilu sesuai dengan amanat Undang-Undang No. 22 Tahun 2007 adalah sebagai berikut:

a. Melaksanakan semua tahapan pemilu dengan tepat waktu.

Bukan pekerjaan mudah untuk melaksanakan tiap tahapan pemilu secara konsisten dan konsekuen sesuai dengan jadwal. Komitmen yang tinggi terhadap jadwal yang telah ditentukan akan mendorong terwujudnya kewibawaan organisasi. Perubahan jadwal apalagi yang dilakukan secara sepihak akan menjadi cikal bakal lembaga penyelenggara ini sebagai bulan-bulanan pihak-pihak yang berkepentingan.

b. Memperlakukan peserta pemilu dan pasangan calon secara adil dan setara.

Dalam negara demokrasi, keadilan merupakan salah satu ide agung (great idea) yang harus selalu diperjuangkan. Keadilan pada umumnya menurut Suseno adalah keadaan dimana setiap orang memperoleh apa yang menjadi haknya ... (2000: 50). Perlakuan yang tidak diskriminatif, egaliter, setara dan fair terhadap semua peserta pemilu akan dan harus menjadi patokan dalam menjalankan tugas-tugas kepemiluan. 


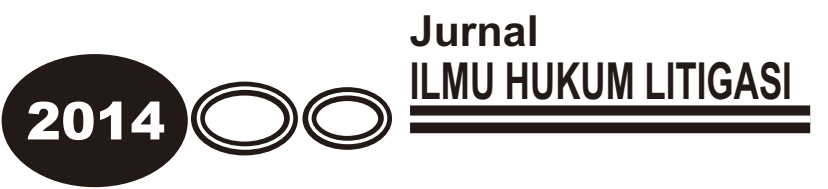

c. Menyampaikan Informasi Kegiatan Kepada Masyarakat.

Salah satu indikator empirik negara demokrasi menurut Robert A. Dahl adalah Citizen also have acces to alternative source of information that are not monopolized by the government or other single group (dalam Taher 1994: xxvii). Dalam kerangka ini, informasi tentang kegiatan pemilu harus menjadi bagian penting dari pendidikan politik rakyat, yang didalamnya memungkinkan rakyat untuk melekukan check, re-check dan cross-check dari berbagai sumber informasi yang variatif tetapi bertanggungjawab.

d. Melaporkan pertanggungjawaban penggunaan anggaran sesuai dengan peraturan perundang-undangan.

Aspek anggaran sebagai salah satu sumber daya organisasi hampir selalu menjadi hal krusial, kontroversial dan debatable. Dalam konteks ini prinsip transparansi dan akuntabilitas penggunaan anggaran harus menjadi "watak" organisasi, sehingga dengannya akan terlahir institusi KPU yang bersih, terhormat dan berwibawa dan bermartabat.

e. Menyampaikan Laporan pertanggungjawaban kegiatan penyelenggaraan pemilu kepada KPU melalui KPU Provinsi. 
Eksistensi laporan dalam manajemen merupakan hal esensial bagi pencapaian tujuan organisasi. Tentu saja laporan dimaksud adalah yang obyektif, akurat dan proporsional. Prinsip pertanggungjawaban (responsibility) akan menjadi barometer sampai sejauh mana suatu program, kebijakan atau keputusan telah berjalan, faktor-faktor apa yang menjadi kendala dan upaya-upaya apa untuk menanganinya. Berjalannya pelaporan dan pertanggungjawaban ini secara tertib akan mendukung lahirnya KPU sebagai institusi yang sehat.

f. Memelihara arsip dan dokumen pemilu serta barang inventaris.

Sudah saatnya setiap aparatur dari keseluruhan "slagorde" pemilu sadar bahwa arsip bukanlah sekedar pelengkap atribut organisasi. Fakta sering menunjukkan bahwa manajemen arsip yang tidak berkualitas telah berimplikasi buruk kepada kinerja organisasi khususnya ketika sampai pada fase pelaporan. Pada sisi lain, arsip dan dokumen pemilu ini akan “bernyawa” ketika bersentuhan dengan kepentingan-kepentingan lain, misalnya kebutuhan data riset untuk studi maupun kepentingan yang lainnya. 


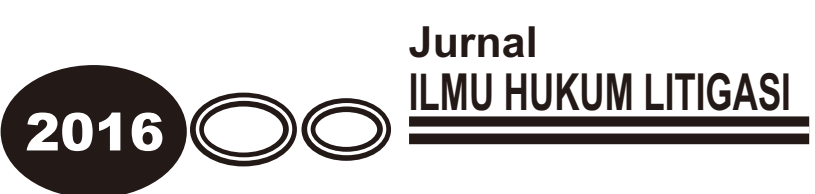

g. Menyampaikan laporan periodik kepada KPU dan KPU Provinsi serta tembusnya kepada Bawaslu.

Karena eksistensi laporan yang demikian penting, maka di tengah hiruk pikuknya kerja demokrasi dengan segala kompleksitasnya ini jangan sampai menelantarkan peran pentingnya dalam rangkaian kepemiluan. Dengan demikian laporan periodik harus disampaikan secara tepat, akurat, dan proporsional.

h. Membuat berita acara setiap rapat pleno dan ditandatangani oleh Ketua dan anggota.

Dalam situasi frekuensi dan intensitas kegiatan yang sangat padat sepanjang penyelenggaraan pemilu, bukanlah hal yang mudah untuk selalu dibuat berita acara setiap rapat pleno. Dalam kaitan ini, dukungan dari jajaran sekretariat sebagai supporting system sangat menentukan.

i. Melaksanakan kewajiban lain yang diberikan oleh KPU dan KPU Provinsi. Sebagai subordinat dari KPU dan KPU Provinsi, maka merupakan suatu keniscayaan pula bahwa KPU Kabupaten/Kota sepenuhnya taat dan konsisten kepada ketentuan-ketentuan organisasi yang telah ditetapkan. Setiap bentuk sikap dan perilaku insubordinatif merupakan wujud penghianatan kepada norma-norma organisasi. 
j. Melaksanakan kewajiban lain yang diberikan oleh peraturan perundangundangan.

Akhirnya apapun yang diamanatkan undang-undang sebagai kewajiban institusional, harus dilaksanakan sebagaimana mestinya. Dengan ini, dirinya dapat terbangun menjadi institusi penyelenggara pemilu yang kredibel, akseptabel, kapabel, dan berintegritas.

B. Peran Aparatur (SDM) Untuk Mendorong Partisipasi Masyarakat Dalam Pemilu.

Sebagaimana dinyatakan dalam konsideran "menimbang" butir b UU No. 22 Tahun 2007 tentang Penyelenggara Pemilu, bahwa pemilu yang langsung, umum, bebas, rahasia, jujur, dan adil, hanya dapat terwujud apabila dilaksanakan oleh penyelenggara pemilu yang mempunyai integritas, profesionalitas, dan akuntabilitas.

Oleh karenanya, institusi KPU harus mampu tampil menjawab tantangan berat seperti itu. Faktor sumber daya manusia atau aparatur yang ada di dalamnya, dengan demikian akan sangat menentukan profil, postur dan kinerja institusi seperti yang diharapkan. Untuk itu, kualifikasi 


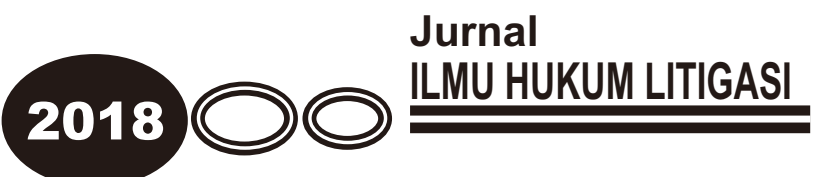

keanggotaan, aparatur dan institusi KPU Kabupaten/Kota haruslah memenuhi kriteria sebagai berikut:

a. Kapabilitas.

Kompetensi dan kemampuan individual harus memancar dari setiap aparatur. Hal ini selaras dengan tingkat pendidikan, pengetahuan, wawasan, pengalaman dan persepsinya berkaitan dengan penyelenggaraan pemilu.

b. Integritas.

Aspek moralitas aparatur menjadi pendukung utama bagi integritas institusi. Hanya anggota-anggota dan aparatur penyelenggara pemilu yang teruji moralitasnya yang dapat menopang lahirnya integritas kelembagaan KPU Kabupaten/Kota secara keseluruhan.

c. Kredibilitas.

Keterpercayaan merupakan modal penting bagi fungsionalitasnya suatu institusi. Aparatur yang kredibel berarti yang dilihat dari aspek personalitasnya layak, patut dan terpercaya untuk menjalankan tugas berat dan mulia itu. 
1. Peran Strategis Pemerintah dalam Pemilihan Umum Upaya mewujudkan pemilihan umum (pemilu) anggota Dewan Perwakilan Rakyat (DPR), Dewan Perwakilan Daerah (DPD), Dewan Perwakilan Rakyat Daerah (DPRD), Presiden, dan Kepala Daerah serta pemilihan umum kepala daerah (pemilukada) yang jujur, bersih, efisien, efektif, beradab, dan demokratis di Indonesia bukanlah pekerjaan mudah. Namun, agenda tesebut merupakan sebuah keharusan kolektif bagi sebuah negara demokrasi untuk merealisasikan cita-cita dan tujuan demokrasi yakni menuju negara yang menjamin kedaulatan rakyat melalui pemerintahan dan wakil rakyat yang dipilih dari rakyat, oleh rakyat, dan bertanggung jawab terhadap rakyat.

Dengan alasan konkret tersebut, dibutuhkan sebuah kekuatan publik dan wadah demokrasi yang betul-betul memiliki komitmen yang kuat dan betul-betul konsisten terhadap tugas dan panggilan untuk menegakkan peraturan pemilihan secara konsisten sesuai dengan peraturan dan perundang-undangan yang berlaku.

Dalam konteks pemilu dan pemilukada, rakyat pada dasarnya merupakan pemegang tahta dan mahkota demokrasi. Sulit dibayangkan jika pemilu tanpa rakyat. Legitimasi pemilu ditakar salah satunya dari kesiapan 


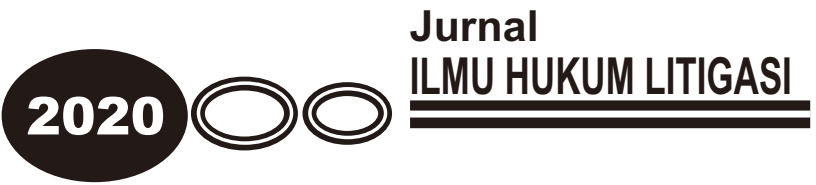

rakyatnya berpartisipasi aktif dalam pemilu serta kesanggupannya dalam menciptakan situasi dan kondisi yang konduksif dan dinamis menjelang, selama, dan setelah pemilu.

Legitimasi pemilu juga ditentukan oleh penyelenggara pemilu dengan dukungan modal kualitas, integritas, profesional, mandiri, transparan, dan akuntabel. Dalam konteks ini, penyelenggara memiliki kewenangan tidak saja merencanakan, melaksanakan, dan mengendalikan penyelenggaraan pemilu, tetapi juga menyusun semua tata cara yang berkaitan dengan tahap persiapan dan pelaksanaan dengan berpedoman pada peraturan yang berlaku. Kewenangan tersebut menyodorkan pemahaman bahwa penyelenggara pemilu memiliki hak dan kewajiban untuk menyelenggarakan pemilu yang dijalankan dengan sebuah tanggung jawab moral demi memajukan demokrasi di pentas kehidupan sosial politik masyarakat Indonesia. Ini merupakan sebuah manifestasi kehendak dan kepercayaan publik kepada penyelenggara pemilu untuk memajukan pemahaman rakyat Indonesia tentang demokrasi dan berusaha semaksimal mungkin mendorong partisipasi politik masyarakat untuk mengambil bagian dalam pemilu secara demokratis. 
Posisi strategis rakyat dan peran sentral penyelenggara pemilu akan mendapatkan maknanya yang istimewa selama mendapatkan dukungan dari pemerintah sebagai kekuatan supra struktur politik. Dengan demikian, kerjasama antara penyelenggara pemilu dengan pemerintah merupakan sebuah keniscayaan yang tak bisa ditawar-tawar dalam pelaksanaan pemilu secara keseluruhan.

Ada beberapa bentuk dukungan penting yang dapat diberikan pemerintah.

Pertama, dukungan sumber dana. Semangat demokratis an sich jelas tidak cukup dalam menyelenggarakan pemilu. Pemilu yang melibatkan rakyat sebagai pemilih sangat membutuhkan ketersediaan logistik yang meniscayakan anggaran yang tidak sedikit. Untuk itulah, kontribusi pemerintah dalam merencanakan serta menyediakan dana pemilu sesuai dengan kebutuhan tak bisa ditawar-tawar lagi. Terlebih, hal yang satu ini memiliki dasar politis dan alasan yuridis. Pada Undang-Undang Nomor 22 tahun 2007 Pasal 114, misalnya, disebutkan bahwa sumber anggaran pemilu adalah APBN. Disebutkan pula pada Pasal 121 bahwa penyelenggaraan pemilu di daerah (KPU Propinsi dan KPU Kab/Kota, Panwaslu) dapat melakukan kerjasama dengan pemerintah daerah dalam 


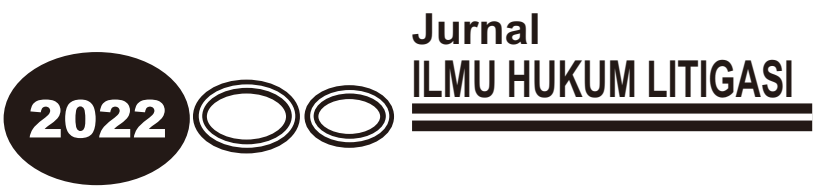

bentuk bantuan dan fasilitasi terhadap penyelenggaraan pemilu dengan penggunaan dana $A P B D$.

Dukungan pemerintah dalam menyediakan dana untuk pemilu tidak hanya dalam besaran yang dibutuhkan penyelenggara pemilu, tapi juga dalam waktu yang tepat sesuai dengan tahapan pemilu. Kurangnya besaran anggaran yang dibutuhkan serta pencairan yang tidak tepat waktu jelas akan sangat menganggu berjalannya tahapan pemilu yang diharapkan semua pihak.

Kedua, dukungan data. Penyelenggaraan pemilu memerlukan dukungan keakuratan data-data yang hanya bisa diperoleh dari pemerintah. Datadata yang diperlukan di antaranya yang berkaitan dengan jumlah kependudukan dan struktur pemerintah hingga ke unit terkecil.

Jumlah kependudukan berkaitan dengan pemutakhiran data pemilih. Sumber pemutakhiran data pemilih adalah daftar penduduk potensial pemilih pemilu (DP4). DP4 yang secara teknis diperoleh dari Dinas Kependudukan setempat dituntut tepat dan akurat. Keakuratan DP4 akan sangat menentukan keakuratan daftar pemilih tetap (DPT) yang akan digunakan dalam pemilu. Selanjutnya DPT akan menentukan jumlah 
tempat pemungutan suara (TPS). Sedangkan keakuratan data struktur pemerintah berkaitan dengan struktur panitia teknis pemilu di lapangan seperti Panitia Pemilihan Kecamatan (PPK) dan Panitia Pemungutan Suara (PPS).

Ketiga, dukungan kondusivitas. Penyelenggara pemilu tidak berkewajiban secara langsung menciptakan situasi yang kondusif selama pemilu. Namun, situasi yang tidak kondusif jelas sangat mengganggu konsentrasi pelaksanaan pemilu yang diharapkan. Bahkan situasi yang tidak kondusif bisa meruntuhkan legitimasi pemilu. Sungguh disayangkan jika pemilu yang mengeluarkan dana yang tidak sedikit kemudian dinilai tidak legitimit hanya karena situasi pemilu yang tidak kondusif. Dalam konteks inilah, sangat diperlukan dukungan pemerintah dalam menciptakan situasi yang kondusif menjelang, selama, dan setelah penyelenggaraan pemilu. Dukungan ini dapat diterjemahkan pemerintah dengan memberdayakan berbagai perangkat yang dimilikinya seperti jaringan pemerintah serta aparat kepolisian dari tingkat pusat hingga unit terkecil dengan peran masing-masing. Pemerintah melalui Rukun Tetangga dan Rukun Warga, misalnya, berusaha menciptakan situasi yang kondusif dengan menyampaikan imbauan atau ajakan kepada warga setempat untuk turut 


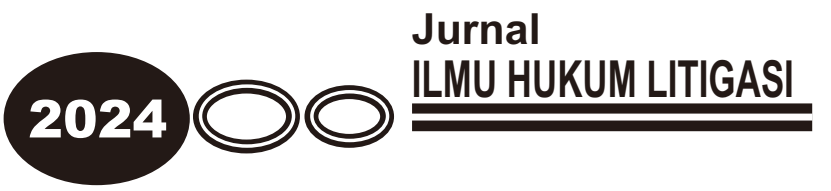

serta menyukseskan pemilu dengan saling mengawal situasi yang kondusif. Begitu pula institusi kepolisian secara langsung menempatkan aparatnya di tiap titik rawan keamanan untuk memberikan rasa aman dan nyaman kepada pemilih dan penyelenggara pemilu.

Keempat, dukungan ruang publik. Secara substansial, proses demokrasi dengan model pemilu baik tingkat nasional maupun daerah akan selalu melibatkan pemerintah pusat dan daerah, sebab keseluruhan pelaksanaan kegiatan pemilu tersebut menggunakan wilayah politik sebagai 'arena bermain'. Tanpa ruang publik, pemilu (yang mengharuskan pemilih datang ke TPS) tidak akan berjalan dengan baik. Karena itulah, dukungan pemerintah dalam bentuk pemberian keleluasaan kepada seluruh stakeholder penyelenggaraan pemilu untuk mengakses fasilitas publik sangat diperlukan.

Ruang-ruang publik yang dapat dimanfaatkan untuk kelancaran pemilu misalnya aula kecamatan/desa untuk sarana pendidikan politik atau sosialisasi pemilu kepada pemilih, lapangan terbuka untuk sarana kampanye bagi partai politik atau kontestan pemilu, atau ruang-ruang sekolah untuk tempat pemungutan suara. Mengingat begitu pentingnya 
fasilitas-fasilitas tersebut, kerja sama yang baik antara penyelenggara pemilu dan pemerintah menjadi sebuah keniscayaan.

Kelima, dukungan sosialisasi. Pemilu seringkali tidak dinilai tidak sukses hanya karena angka partisipasi pemilih rendah. Partisipasi pemilih yang rendah juga suka menjadi ukuran rendahnya legitimasi calon terpilih. Karena itulah, sosialisasi pemilu kepada pemilih menjadi agenda yang sangat penting. Dalam konteks inilah, dukungan aktif pemerintah dari tingkat pusat hingga kelurahan/desa dalam bentuk sosialisasi kepada warga amat diperlukan.

Sosialisasi pemilu dapat dilakukan pemerintah untuk memberi keyakinan tentang arti penting pemilu kepada masyarakat setempat sehingga mengurangi jumlah golput. Melalui sosialisasi, pemerintah juga dapat menyampaikan kepada masyarakat tentang kewenangan penyelenggara pemilu dan kebijakan pemerintah dalam konteks pemilu.

Keenam, dukungan sistem. Partisipasi aktif pemerintah juga diperlukan untuk mendukung kesekretariatan KPU dalam melaksanakan berbagai tahapan pemilu. Sebagai supporting staff KPU, profesionalisme aparat pemerintah amat menentukan keberhasilan tiap tahapan pemilu, dari 


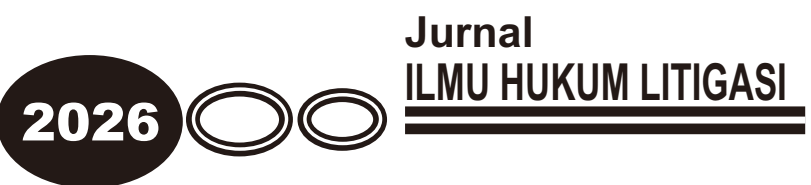

sosialisasi, pendistribusian surat suara dan kotak suara, sampai penetapan pemenang. Demikian pula keterlibatan aktif aparat pemerintah menjadi PPK, PPS, dan KPPS dimungkinkan mengingat keterbatasan penduduk yang memiliki kualifikasi untuk dapat menjadi anggota panitia pemilu.

Di luar tahapan penyelenggaraan pemilu, supporting staff KPU tidak kalah pentingnya. Jajaran kesekretariatan KPU yang merupakan pegawai negeri sipil (PNS), baik organ internal KPU maupun yang ditempatkan pemerintah daerah, amat menentukan kelancaran berbagai agenda KPU. Karena itu, selain profesionalisme, diperlukan juga keikhlasan dan sinergitas antar staf sekretariat dan dengan komisioner.

2. Peran strategis KPU dalam melaksanakan Pendidikan Demokrasi pada masyarakat.

Selama ini KPU sebagasi lembaga penyelenggara Pemilihan Umum, yang mengalami penilaian buruk dari berbagai pihak baik itu institusi ataupun dari masyarakat, terkait dengan penetapan data pemilih (DPT) KPU tidak mengelola data kependudukan dari awal, namun menerima data dari pemerintah yang disebut DP4.

Dari DP4 itulah KPU baru mengelola pendataan mengenai pemilih dari DPS (Daftar Pemilih Sementara) Ialu DPT (Daftar Pemilih Tetap). Maka 
bila selama DP4 yang diberikan pemerintah kepada KPU itu tidak akurat maka selamanya mengenai daftar pemilih selalu menjadi masalah, dan yang dipersalahkan selalu KPU padahal titik masalahnya bermula dari pemerintah. Untuk itu kewenangan KPU sebagai penyelenggara pemilu seyogyanya ditambah agar kegiatan kepemiluan betul - betul optimal mulai dari tahapan awal sampai tahapan akhir pemilihan terutama kegiatan-kegiatan yang selalu bermasalah dan yang akan berpotensi bermasalah, melihat fakta seperti itu agar KPU optimal dalam melaksanakan tugas dan fungsinya digagas sebagai berikut :

a. KPU diberi tugas tambahan yaitu malaksanakan pendidikan demokrasi kepada masyarakat secara terus menerus dan alat ukurnya adalah partisipasi, bukan hanya melaksakan sosialisasi (pemberitahuan) saja yang alat ukurnya bias.

b. KPU harus meningkatkan kerjasama dengan setiap pihak berkepentingan mulai dengan instansi seperti dengan kominfo atau dengan lembaga-lembaga masyarakat yang ada seperti lembagalembaga keagamaan. 


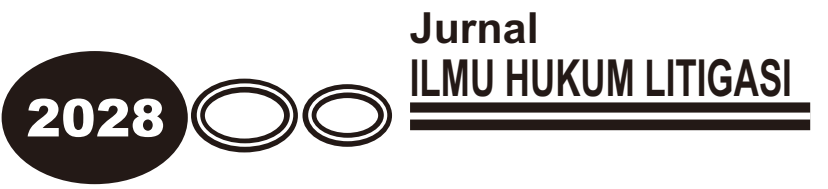

c. Bagi KPU Propinsi, Kabupaten/Kota yang melaksanakan Pemilihan Kepala Daerah, diberikan kewenangan untuk membuat aturan yang bersifat regulatif.

\section{SIMPULAN DAN SARAN}

\section{A. Simpulan}

1. KPU dalam melaksanakan tugasnya harus melakukan kerjasama dengan instansi-instansi lain, lembaga-lembaga kemasyarakatan yang ada di daerah, karena lembaga KPU itu dalam sistem ketatanegaraan sifatnya auxiliry (penunjang), maka penguatan dalam hubungan dengan pihak luar merupakan harga mati.

2. Penguatan terhadap lembaga KPU sendiri dengan membuka ruang dan mengembangkan fungsinya dengan cara diberi tugas baru yaitu melaksanakan pendidikan demokrasi secara berkelanjutan pada masyarakat. Serta diberi kewenangan untuk membuat aturan yang sifatnya mengatur bukan hanya keputusan, terkait dalam melaksanakan pemilihan kepala daerah dan wakil kepala daerah. 
B. Simpulan

1. Setiap langkah dan kebijakan KPU akan diterima oleh publik (masyarakat) maupun peserta pemilu bila kebijakan tersebut akseptabel, maksudnya apapun yang diprogramkan oleh lembaga akan diterima dan diikuti oleh masyarakat.

2. Adanya optimalisasi pihak pemerintah dalam melakukan publikasi pelaksanaan pemilu dari pusat sampai pemerintahan tingkat desa bahkan organisasi masyarakat yang dalam hal ini RT dan RW harus dilibatkan. 


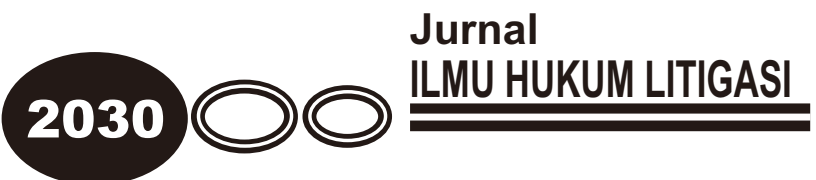

\section{DAFTAR PUSTAKA}

Ball, Allan R. 1975, Modern Politics And Government, London: The Macmillan Press Ltd.

Blondel J.1955, Comparative Government An Introduction. Second Edition, London: Prentiee Hall Harvester Wheatsheaf.

Edward III, Geirge, 1989, Implementing Public Policy. Washington D.C: Congresional Quarterly Press.

Grindle, Merilee. (ed.). 1980. Politics and Policy Implementation in the Third World. New Jersey: Princeton University Press.

Jones, Charles O. 1984. An Introduction to the Study of Public Policy: Third Edition. Callifornia: Brooks/Cole Publiching Company.

Robbins, Stephen P. 1990. Organization Theory: Structure, Designs and Apllications. Third Edition. London: Practice Hall International Editions.

Suseno, Franz Magnis, 2000, Kuasa dan Moral, Jakarta: PT. Gramedia Pustaka Utama.

Taher, Elza Peldi (ed).1994, Demokratisasi Politik, Budaya dan Ekonomi Pengalaman Indonesia Masa Orde Baru, Jakarta: Yayasan Paramadira.

Undang-Undang No. 22 Tahun 2007 tentang Penyelenggara Pemilu. Undang-Undang No. 15 Tahun 2011 tentang Penyelenggara Pemilu. 